\title{
The Use of the Stream Length-Gradient Index in Morphotectonic Analysis of Drainage Basins in Poços de Caldas Plateau, SE Brazil
}

\author{
Carolina Doranti-Tiritan, Peter Christian Hackspacher, Daniel Henrique de Souza, \\ Marli Carina Siqueira-Ribeiro \\ Instituto de Geociências e Ciências Exatas, UNESP, Rio Claro, Brazil \\ Email: cadoranti@gmail.com
}

Received 10 August 2014; revised 2 September 2014; accepted 25 September 2014

Copyright (C) 2014 by authors and Scientific Research Publishing Inc.

This work is licensed under the Creative Commons Attribution International License (CC BY).

http://creativecommons.org/licenses/by/4.0/

(c) (i) Open Access

\begin{abstract}
The Poços de Caldas Plateau is formed by the alkaline intrusion of Poços de Caldas and surrounding metamorphic basement. It is characterized as a remnant of the South American Planation Surface resulted from erosional events from Late Cretaceous-Paleogene transition. Poços de Caldas Alkaline Massif (PCAM) was formed during alkaline volcanism event from the Late Cretaceous. It is located on the west side of the Mantiqueira Mountain Range, characterized by alkaline rocks and topography reaches over $1700 \mathrm{~m}$ high. A major feature of denudation is the development of the "circular drainage", a particular feature of some caldera and other circular or concentric structural features. Recent tectonic movements may critically affect regional geomorphology by influencing river patterns and orientations. The morphometric analysis shows that some rivers are controlled by reactivated faults, however, in some regions the lithology has major influence in the rivers development.
\end{abstract}

Keywords

Component, Formatting, Style, Styling, Insert

\section{Introduction}

The southeast Brazilian passive margin records a long history of tectonic magmatism events since the Late Jurassic. Those events were consequence of the South Atlantic Ocean [1] [2]. The continental breakup preceded by 
intense tholeiitic magmatism in south and southeast of Brazil, with magmatic climax at $132 \mathrm{Ma}$ [3].

After the rifting process has ceased, an epeirogenic uplift of the continental crust has started in response to the drifting of the South American Platform over a thermal anomaly that accompanied an intense alkaline and basaltic magmatism [4]. This alkaline volcanism from the Late Cretaceous generates a very particular structure on the Brazilian southeast named Poços de Caldas Alkaline Massif (PCAM). The structure covers over $800 \mathrm{~km}^{2}$ [5] and it is the greatest from the set of intrusions that form the Poços de Caldas-Cabo Frio Lineament [6]. The Poços de Caldas massif is mainly constituted by subvolcanicphonolites (tinguaites), nephelinesyenites (NeS), and mostly altered volcanic phonolites, in part enclosing the overlying eolian Botucatu sandstones and some Serra Geraldiabases [7] [8].

The topography is characterized by dissected plateau with irregular topographic ridges and peaks with elevations between 900 and $1300 \mathrm{~m}$ (a.s.l.) on the metamorphic basement and from 1300 to $1700 \mathrm{~m}$ (a.s.l.) on the PCAM region. The geomorphological development of most part of the highlands on southeast of Brazil was explained by the [9] pediplanation scheme or by the correlation between the pediplanation with favourable climatic conditions and intermittent uplift and dissection [10]. Accoording to these concepts erosional surfaces were recognized in the area nevertheless, there are different point of views about the age, origin and structure. In these sense the main objective of this work was to present information about the summit heights in the area and try to associate with palaeosurfaces using techniques that allows identifying the process that is controlling the landscape evolution in the region.

Some geomorphic indices have been developed to identify areas experiencing rapid tectonic deformation [11] [12]. Geomorphic indices are particularly useful in tectonic studies because they provide a rapid evaluation of large areas and can be obtained easily from topographic maps or aerial photos [13]. Moreover, in recent decades, the increasing usefulness of GIS software has made it easier to undertake quick and detailed processing of data [14]. The Stream Length-Gradient Index (SL Index) is one of the quantitative geomorphic parameters included in morphotectonic investigation. In the regional scale of analysis, the SL Index can be a useful tool to detect tectonic displacements and reactivation [15]. The longitudinal profile of a channel determines the gradient of a river and their behavior along the channel from the headwater to mouth [16].

The present study sets out to better understand the configuration of the long-term landscape evolution of the Poços de Caldas Alkaline Massif that is part of the southeast Brazilian highlands, providing insights on the behaviour of the coupled magmatic tectonic-erosional system.

\section{Study Area}

\section{Geological Setting}

The Poços de Caldas Plateau (PCP) is located in the southeast part of Brazilian highlands in the limit between São Paulo and Minas Gerais states and on northwest of Rio de Janeiro State. As described in [17], this is plateau as a small morphostructural unit represented by a high land relief, with a circular configuration. The highest part (above $1400 \mathrm{~m}$ ) of the plateau is the Poços de Caldas Alkaline Massif (PCAM) structure and the lower part (between 900 and $1400 \mathrm{~m}$ ) is part of the metamorphic basement called North Crystalline Zone (NCZ). The PCP emplaced in the Guaxupé-Socorro Nappe is limited on north by the São Francisco Cráton, on south an east by the RibeiraOrogenic Belt and west by the Paraná Basin.

The area is located in the Mantiqueira Geological Province context, which is an orogenic system parallel to the south Atlantic coast on southeast and south of Brazil developed in the Brazilian orogeny cycle [18]. The Mantiqueira Province is a large, complex structural province deformed by the Neoproterozoic/Early Paleozoic BrasilianoOrogenic event in South America, related to the Pan-African orogeny. The central part of the province, is formed by the Brasilia SulOrogen, RibeiraOrogen and the interference zone between the Apiaí, São Roque and Embu terrains, that was originated from a sequence of collisions from the 630 to $510 \mathrm{Ma}$ [19]. The map on Figure 1 illustrates the location of the study area located in the Brasilia Sul belt delimited by the São Francisco craton, Parana Basin and Ribeira belt.

The PCAM is located in the nappe system in south-southwest São Francisco Craton. Represents the southern extension of the Brazilian belt and describes an inverted metamorphic pile (stack) of green schist facies (bottom) toward amphibolite facies (Carmo da Cachoeira e Aiuruoca-Andrelândianappes) and high pressure granulites in the top, under a high temperature allochtonous (Socorro-Guaxupénappe).

The Guaxupé-Socorro Nappe has a very complex intrusive and metamorphic history and was attached to the 


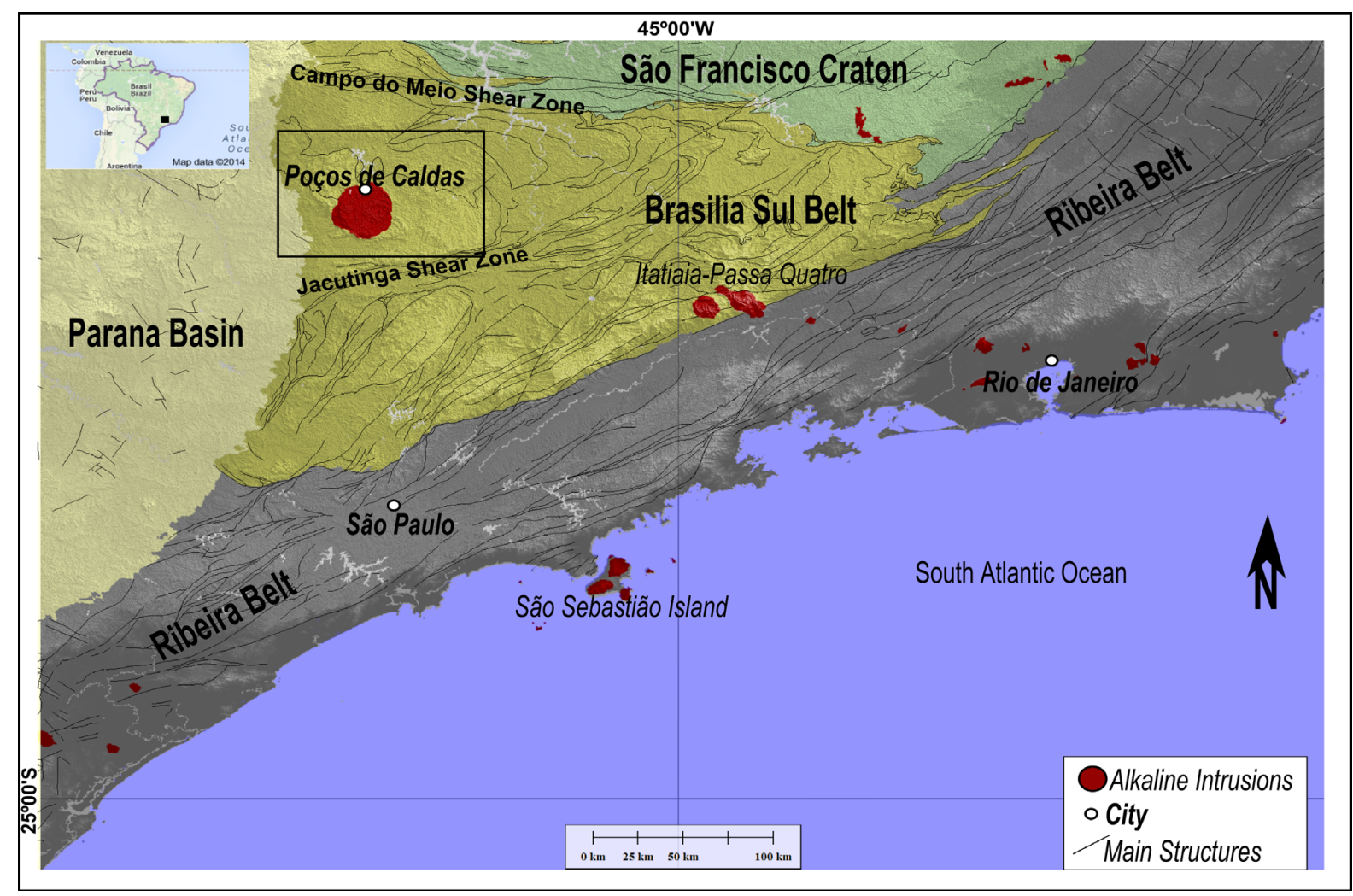

Figure 1. Regional geology map shown the principal features (Pre-Cambrian basement; the Parana Basin and the Cenozoic alkaline intrusions).

southernmost portion of the Brasília Belt and later transported during the Neoproterozoic over the São Francisco Craton in an east direction. Two possibly related segments are recognized in the Nappe, the northernmost triangular Guaxupé block, with its base covered by sediments of the Paraná Basin, and the southern structure, Socorro [20] [21]. Several Archean to Proterozoiuc units were recognized within the Guaxupé block: the complexes Caconde (supracrustal quartz gneisses), Alfenas-Guaxupé (assorted granulites of igneous origin), Varginha (high-grade gneisses and paragranulites) and Pinhal (migmatitic and deformed granite facies) [22].

The basement areas that constitute the Guaxupé block and the surrounding regions are cut by several linear features interpreted mostly as old reactivated faults. The predominant fault direction is NE and NW, parallel to the two most commonly observed structural trends in the basement of southern and SE Brazil. Observation on a regional scale show an increase in the amount of the NE and NW fractures in the region around PCAM. As well as an arching of structural trends in the basement rocks, to the east, thus creating a zone of weakness that may have channelled the flow of the PCAM magmas [23]. The emplacement of the PCAM was controlled by the passage of the Trindade plume, farther north, which may have been deflected to the south by the deep keel of old and cold cratonic areas, such as the Sao Francisco craton, generating magmas that upsurge into the surface along deep pre-existing structures [6]-[24].

This event formed the Poços de Caldas-Cabo Frio Magmatic Lineament, as defined by [25], is a WNW-ESE structural feature, $60 \mathrm{~km}$ wide by $1150 \mathrm{~km}$ long, developed from Jaboticabal (Northern Sao Paulo State) eastwards, up to the Almirante Saldanha Bank, region of the boundary between continental and oceanic crusts. Indeed, the topographic and lithologic features, shows prominent tinguaite ridges that suggest that the massif represents the upper part of a caldera-like structure, with early appearance of tinguaites as ring dikes, followed by collapse and the intrusion of the inner tinguaites and some outpouring of phonolites, culminating with the late intrusion of most nephelinesyenites [7] [8].

Geologic observations on the alkaline massif show that the miaskitic-intermediate nephelinesyenites are somewhat older than the more evolved agpaitic varieties. Many elongated nephelinesyenite bodies are confined to the rim areas, a preferred site for the intrusion of these magmas and an indirect evidence for the existence of 
"ring structures"; the northern-rim fluorite-bearing grey nephelinesyenite is clearly an incomplete ring dike [5]. In addition, it can be found in some areas of the massif, isolate sediment bodies surrounded by neighbourphonolitic rocks with intrusive contact and ramdom strikes and dips. They were correlated to the Botucatu Fomation by [26] and [7], which suggested a simultaneous deposition with the alkaline pyroclastic rocks and a general dip minor than 20 degrees to the centre of the alkaline complex to justify the caldera collapse. Figure 2 is showing the main geological setting of the area.

\section{Morphometric Analysis}

The analysis of Geomorphic Indexes of drainage systems allows detecting recent tectonic activity and uplifting [26] as river channels are very sensitive to changes in the parameters that control their shape and gradient [27][29]. Rivers tend to develop equilibrium profiles in relative short times, and consequently, anomalies in the river network systems, can be considered recent tectonic activity in case e other factors as lithology or climate are discarded [30]. Two geomorphic indexes were used in this paper the River Longitudinal Profiles and the Slope Gradiente Index (SL). These techniques are used to identify areas experiencing rapid tectonic deformation [11] [12]. Geological and topographic maps were also analysed in order to delineate areas of accordant summit heights.

\subsection{River Longitudinal Profile}

The longitudinal profile is a curve obtained from the relationship between height $(\mathrm{H})$ versus distance downstream (L) of a channel [31] [32]. Deviations from a concave-up shape of stream longitudinal profiles may indicate an instability state of channels due to tectonic, climatic or rock-type perturbations [33]. In particular, convex segments can be investigated to evaluate tectonic perturbation at different scales, from the whole chain to local structures (c). As determined in [34] the semi-logarithmic graph of a profile allows analysing a river, where a graded river would appear as a straight inclined line. Thus, any difference between the straight line and the profile could reveal how and where the longitudinal profile of the river would be ungraded. According to [35] conception, the semi-logarithmic profile allows the global analysis of the river and indicates the difference from a graded profile highlighting the main points of inflection at the gradient line (knick points) and leading to an interpretation based on geological and geomorphological factors.

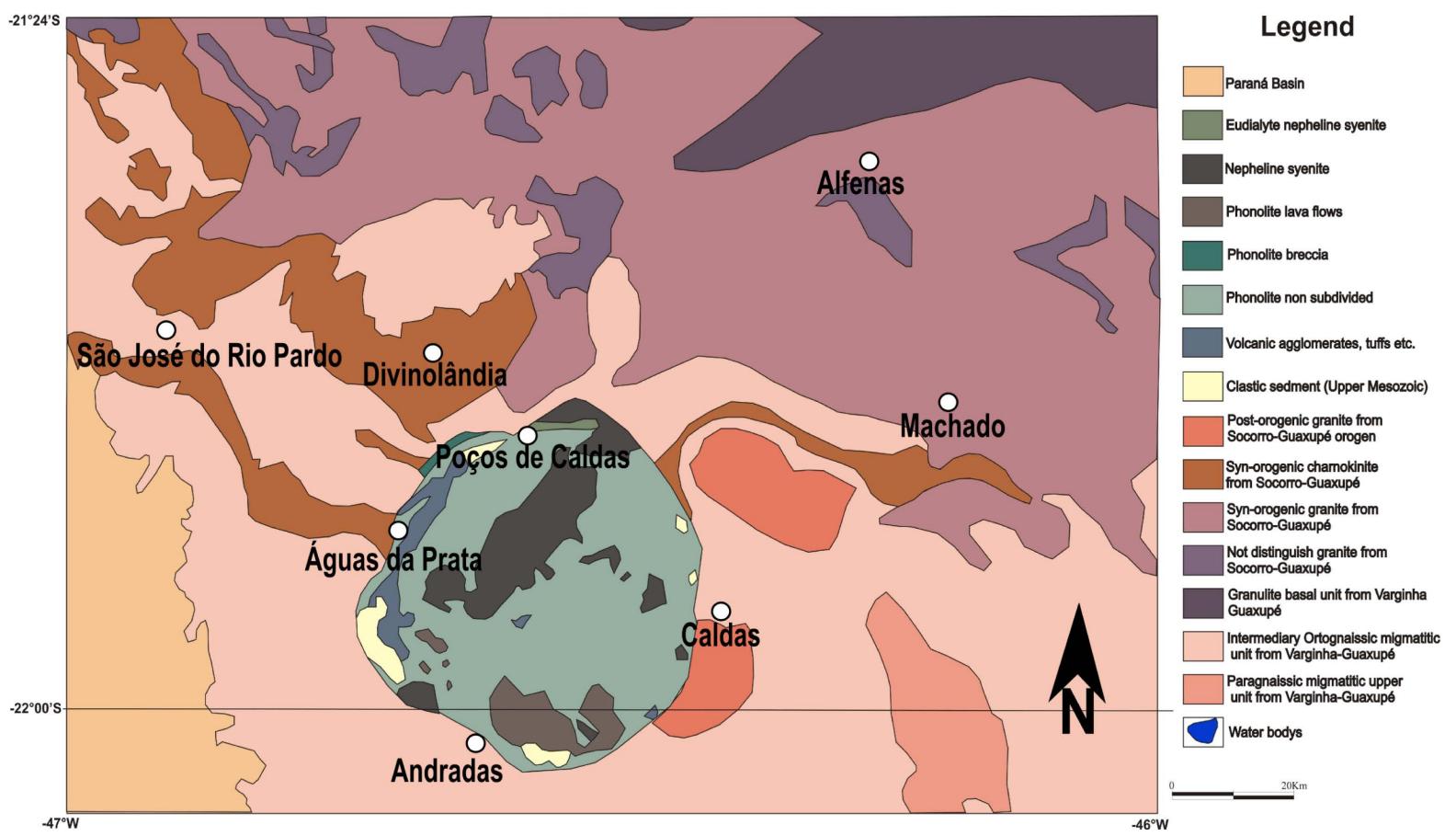

Figure 2. Geological map of the region and the main cities (modified from [5] [28]). 


\subsection{SL Index}

Proposed by [35] the stream gradient index as a practical resource to determine anomalies in the natural concavity at the longitudinal profile. The index allows the normalization of the gradient values and the identification of anomalous points in each section of the river from headwaters to mouth. The stream gradient index by stretch of river is calculated by the equation:

$$
\mathrm{SL}=\Delta \mathrm{H} / \Delta \mathrm{L} \cdot \mathrm{L}
$$

where $\Delta \mathrm{H}$ is the difference of altitude between two points in the watercourse, $\Delta \mathrm{L}$ is the length of this stretch and $\mathrm{L}$ is the total length of the channel. According to [36] the SL Index may be interpreted as an indicator of the available stream power at a particular channel reach [12]. The SL Index remains approximately constant along a graded stream and variations in the SL Index appear to be attributable to tectonic or to structural and lithological controls [37]. Usually, it is very sensitive to changes in channel slope and is applied to evaluate relationships between possible tectonic activity, rock resistance and topography [11]-[38]. The SL Index remains approximately constant along a graded stream and variations in the SL Index appear to be attributable to tectonic or to structural and lithological controls [37].

\section{Results and Interpretation}

The topographic map on Figure 3 shows the summit levels from the region. According to [36] the concentration of summit heights in certain heights correspond with the scheme of surfaces, pediments and terraces proposed by [39] [40]. Four topographic levels were defined ranging from $<900$ to $>1500 \mathrm{~m}$ of elevation. The differences in elevation in the lower levels appear to be mostly due to differential weathering and erosion. However the upper intermediate level (900 - $1200 \mathrm{~m}$ ) shows that part of the metamorphic basement is in the same level as the alkaline rocks of PCAM. The upper level is formed by the top of the circular structures of the PCAM and the MaciçoPedraBranca on SE. This level is supposed to have been formed before the breakup of the Gondwana continent according with [9], although this level was formed after the PCAM intrusion, which means they cannot be older than $80 \mathrm{Ma}$. It is possible to see that this is just one of the several limitations in using only the

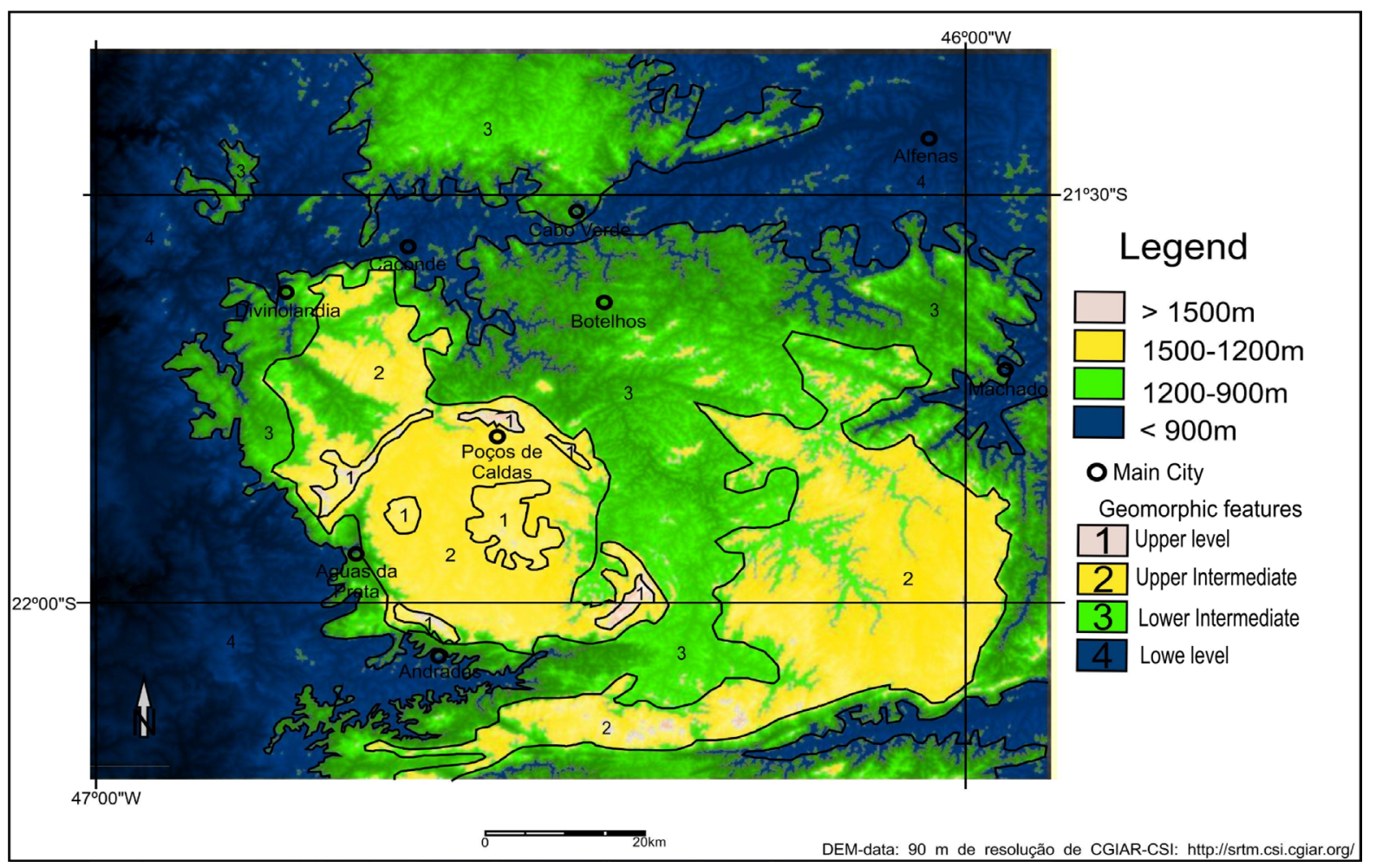

Figure 3. Hypsometric map with the four mean surface levels. 
summit heights as evidence of erosional surfaces as postulated by [9].

The drainage network of the region is distributed in several ways, the main types are dendritic, parallel, trellis and rectangular. In the areas close to the alkaline massif lies annular drainage pattern. All this different drainage patterns means several types of controls like lithology, structure and topography. The SL Index where calculated for the main stream of the rivers and where interpolated on the map (Figure 4). The results show that most of the rivers are controlled by the intense pattern of NW-SE, NE-SW e NNE-SSW trending faults that can also be seen in the longitudinal profile of the main rivers.

According to [41], the E-W and ENE-WSW lineaments are very evident in the area and they related them to the OuroFino-Jacutinga shear zone in the south part of the study area (Figure 5). In addition, the directions WNW-ESE are very common and are related to the Campo do Meio shear zone on the northern part of the area. N-S and NW-SE lineament directions are also very abundant in the region and the authors attribute them to Cenozoic tectonic movements, however part of them are related to the Pre-Cambrian structures. The lineament relative frequency suggests two main tectonic moving directions that are expressed on the NE-SW and NW-SE morphology. The N-S and ENE-WSW directions cross the PCAM and are related to Upper and Upper Intermediate levels indicating also Cenozoic movements (Figure 6) [42]. Areas characterized by pronounced accordant summit heights are associated with highly dissected terrains and the low and moderate SL Index corresponds with streams with few knickpoints that are adjusted to the major rivers (Figure 8). However, this is not applied by the Machado (1), Peixe (2), Pardo (3) and Taquari (6) rivers as they are cut by these faults in several parts of the main stream.

The longitudinal profiles from NCZ show the fault controls over the main rivers. The SL Index curve shows that the highest values coincide with the knickpoints regression. Those anomalies are attributed to the structure that cut the river segments in several parts from the upper to the lower course. On the other hand Antastiver in PCAM does not present the same pattern as the course is following the structures and not being cut by them. The Antas River cross the ring structure of PCAM on the north shows that it was installed after the cooling of the massif. The Peixe River longitudinal profile (Figure 6, n. 2) shows several knickpoints coinciding with the highest SL Index values. Those values are related to the NW-SE faults that are perpendicular to the main stream. Peixe River is located in the NCZ and is related to the Lower Intermediate and Lower Levels defined in Figure 3. Pardo River is the greatest in the region serving as regional base level (except Machado e Peixe River that are

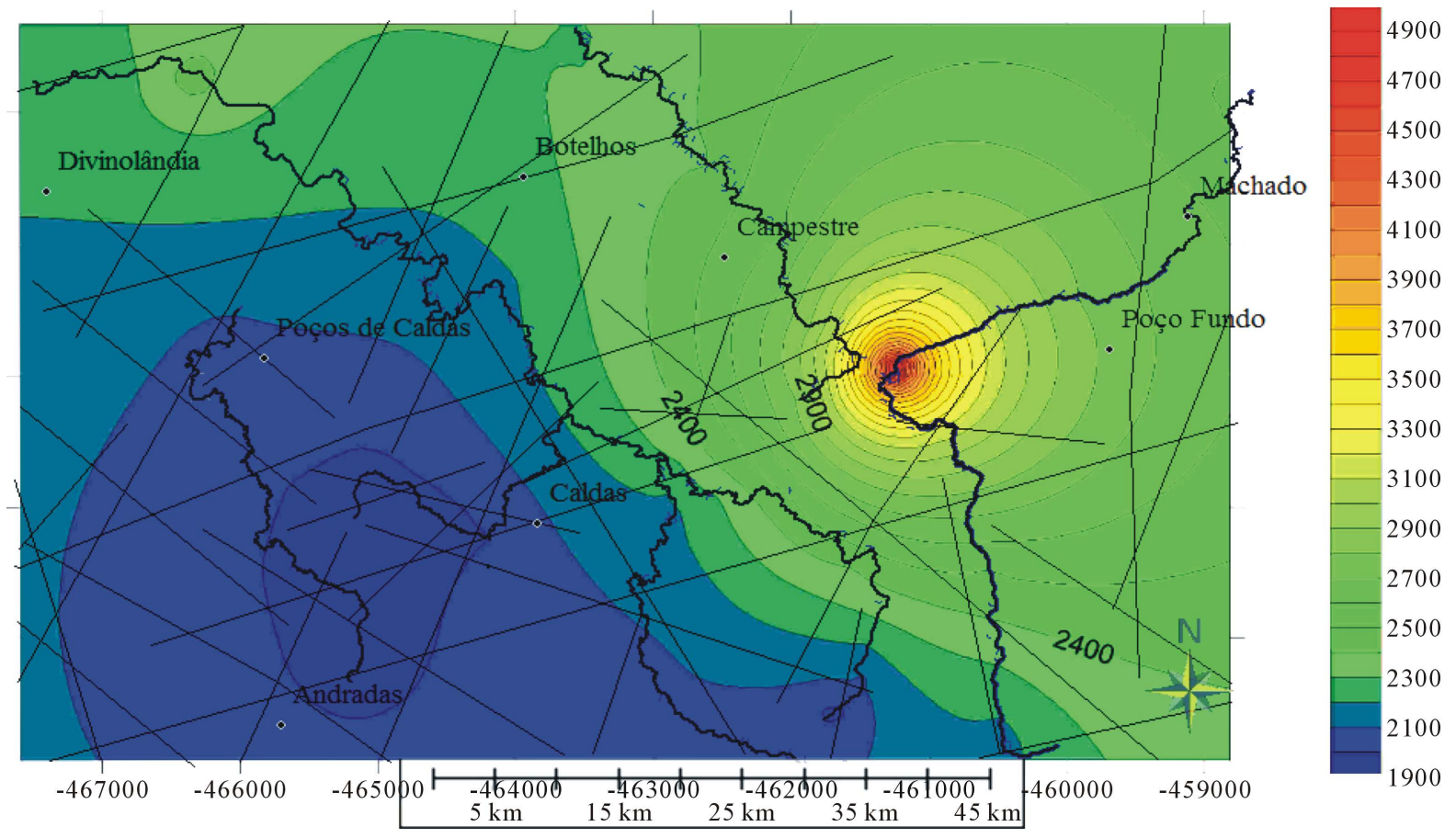

Figure 4. Regional pattern of the stream-length gradient index in the study area. 1. Machado River; 2. Peixe River; 3. Pardo River; 4. Capivari River; 5. Antas River; 6. Taquari River. The main structures are adapted from [24]. 


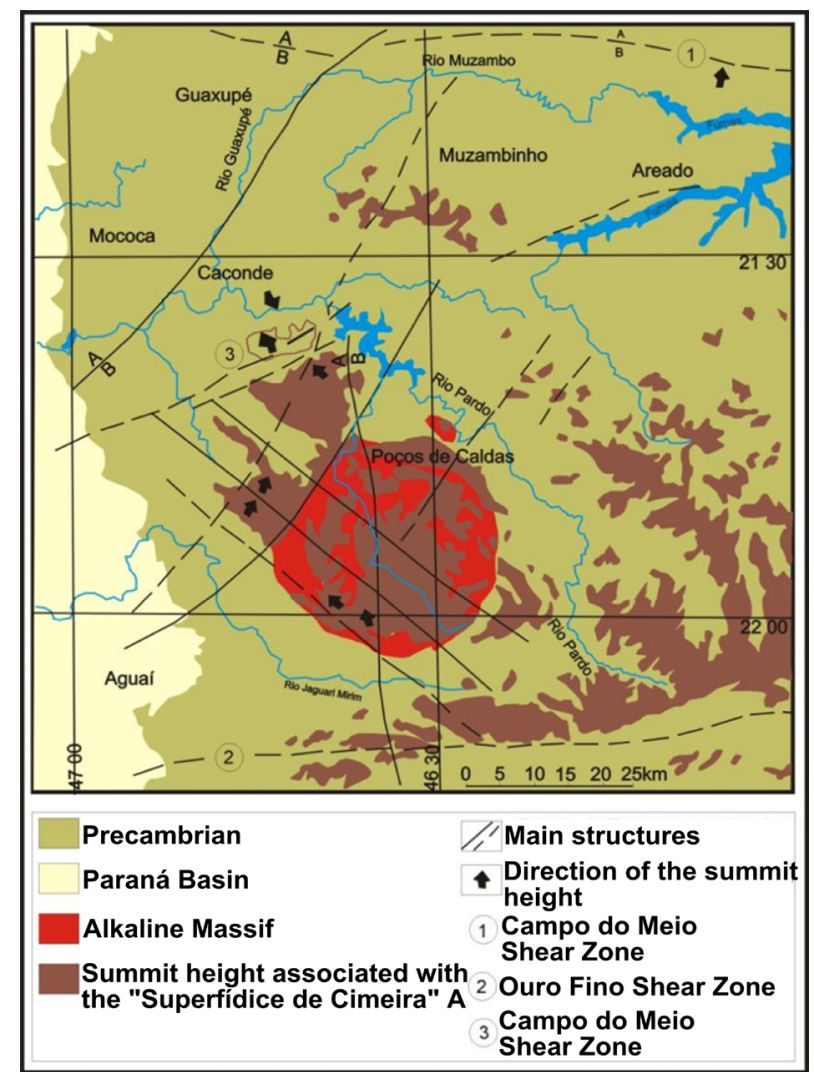

Figure 5. Morphotectonic elements of the Poços de Caldas Plateau region (Modified from [41]).

also tributaries of the Rio Grande drainage basin). The SL Index highest values coincide with the knickpoints on the longitudinal profile (Figure 6, n. 3). The river belongs to the NCZ and the main stream cross the levels Upper Intermediate, Lower Intemediate and the Lower. This river crosses the Paraná Basin in the west side of the region, although in this work it was considered just the upper course that belongs to the crystalline basement.

Machado River is a drainage basin that deserves some special attention, as the main stream has distinct morphologies. From the upper to middle course it flows from on a smooth plateau with about $1250 \mathrm{~m}$ high (average) and present characteristics like wide and open valley, suspended sediment, several meanders and abandoned meanders, it runs from the south to the nor-northwest until the middle point where it fits on a fault lineament with SW-NE direction.

From this point the river morphology changes into a bedrock channel, forming a V-shaped valley. These characteristics remain about $20 \mathrm{~km}$ when the channel starts to present a meandering morphology until reaches the mouth. All this features are indicating an inversion of the drainage that probably was running to the south and in some moment starts running to north and northeast. This change in the river direction was associated with a drainage capture [41]. The Longitudinal Profile of Machado River shows this drastic change in elevation (400 $\mathrm{m}$ ), where the SL Index value is the highest comparing with the all other river values. The upper course belongs to the upper intermediate level while the lower course flows over the lower level.

The structures cutting the upper course are not influencing the dynamic of river channel. Figure 7 calls attention for the Machado River longitudinal profile, each letter A, B and C represents one of yours segments as follows, Upper course, Medium course and Lower course. The pictures in Figure 8 show the differences on the river morphology in each part of its course, indicating an inversion of the river direction, probably from N-S to a S-N/SW-NE, caused by a river capture. [43] had already called attention for the behaviour of the Machado River and also applying morphometric analysis for the whole drainage basin, showing that it is controlled part for the lithology and part for the structural lineaments. The authors also suggest a change in the course, but there are not enough tools to affirm. 

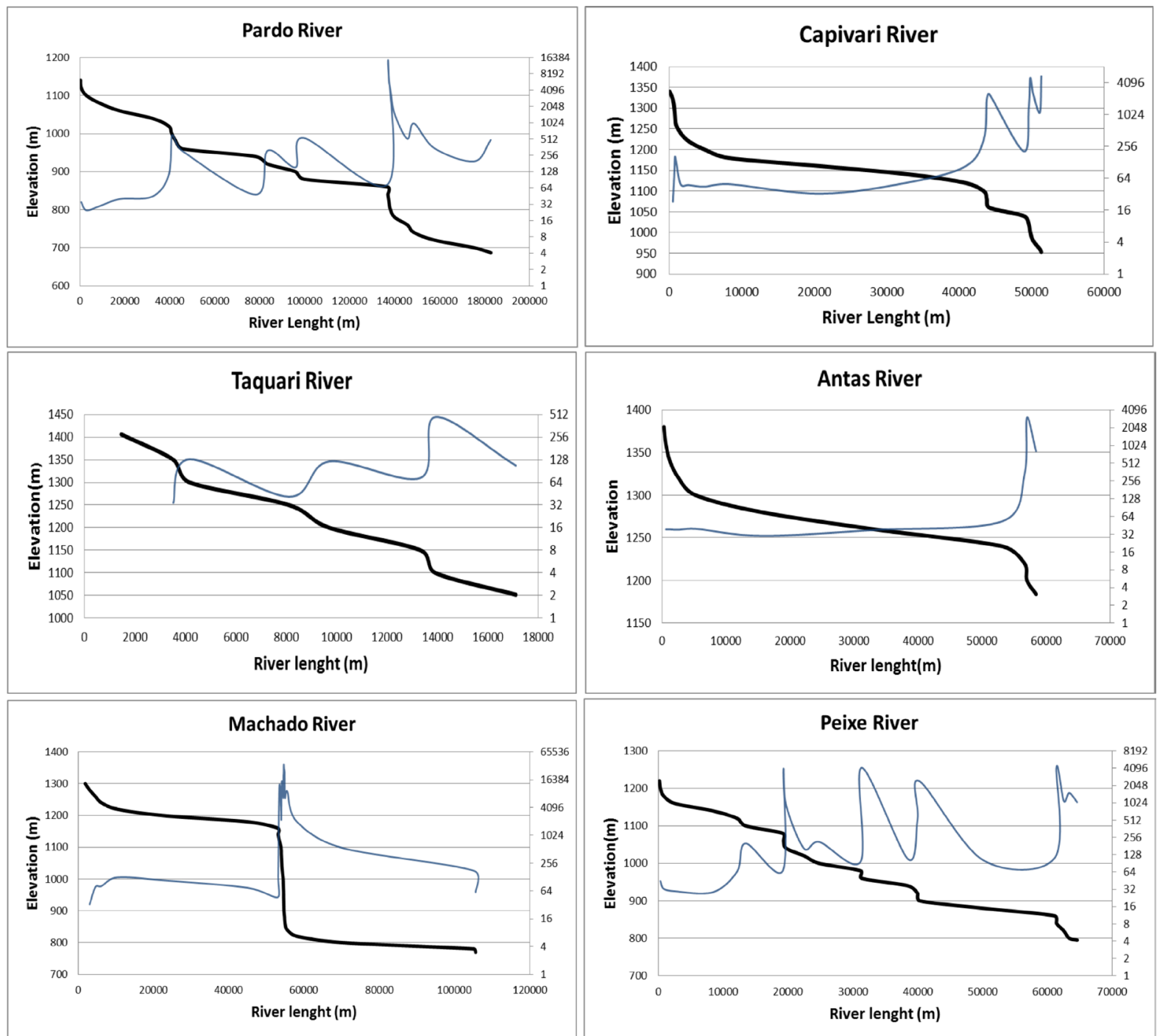

Longitudinal Profile

SL Index

Figure 6. Longitudinal profile and SL Index of the main rivers of the study area.

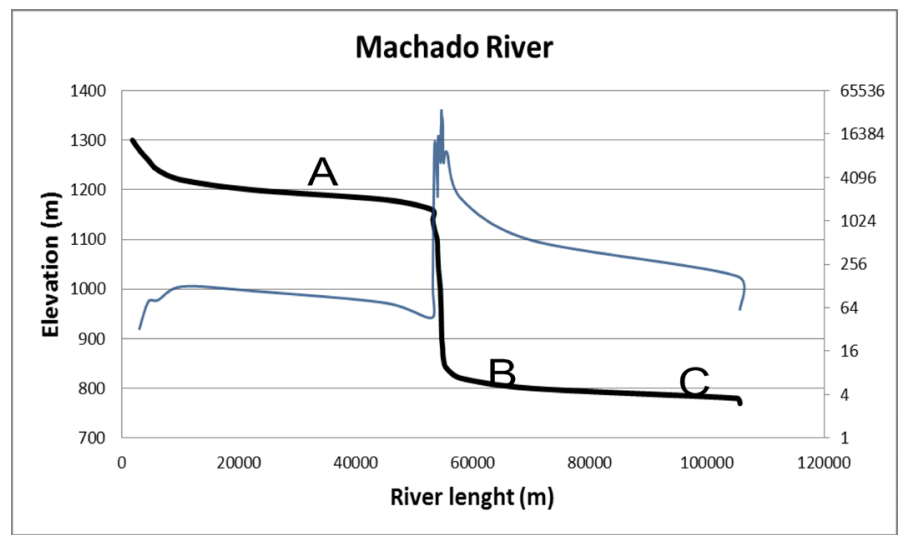

Figure 7. Machado River longitudinal profile. A: Upper Course; B: Medium Course; C: Lower course. 

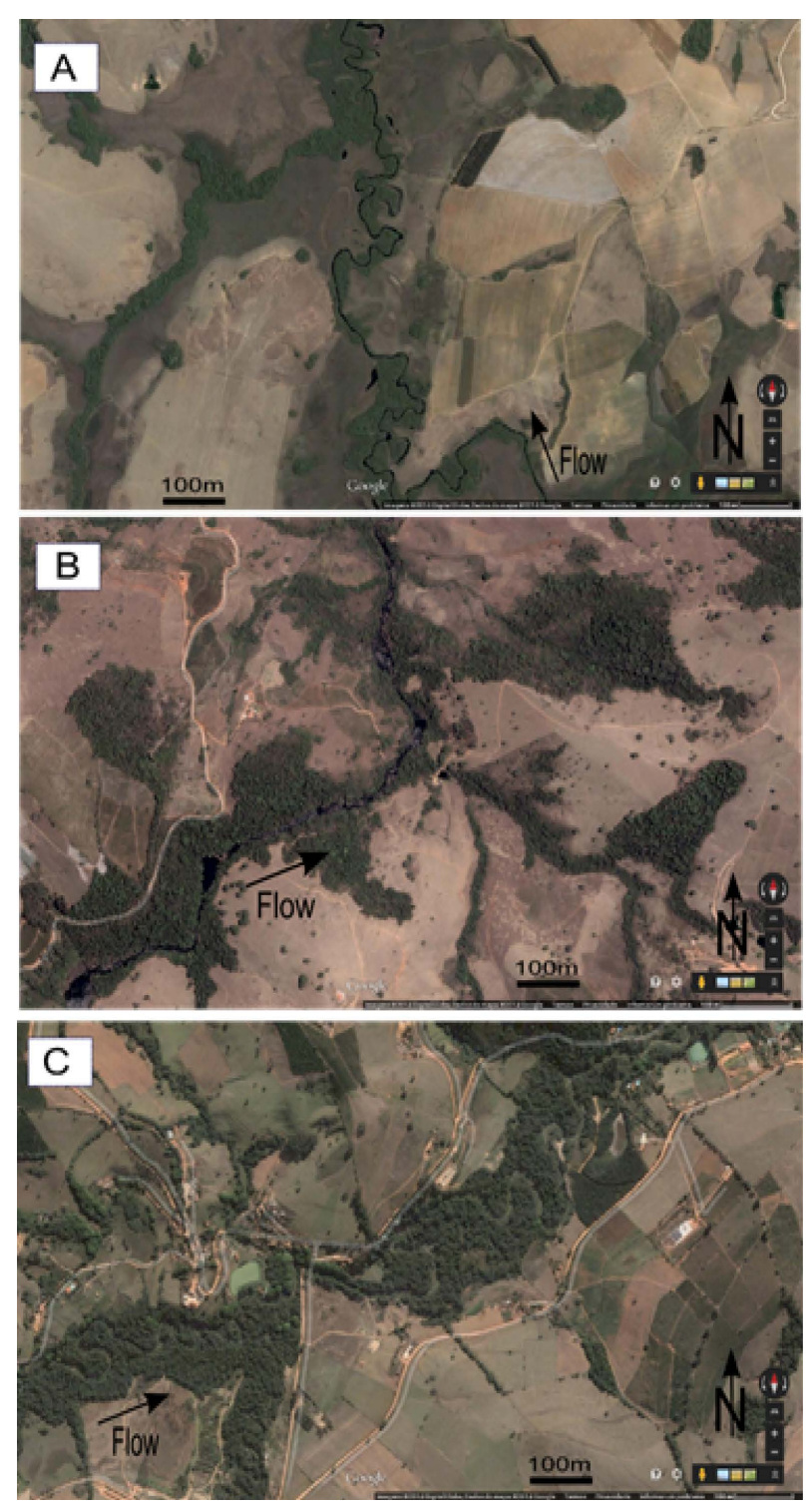

Figure 8. Morphology of Machado River in each segment (A) Upper course; (B) Medium course; (C) Lower course.

All these topography and drainage patterns, that are very common in southeastern Brazil, are providing evidence of recent uplift, block-faulting, and river capture, all of which are symptomatic of active tectonics [44]. Although, the morphometric analysis shows that the main river basins are controlled by fault lineaments, apatite fission track ages shows that most of them should have been reactivated on the Early Cretaceous and specially the Late Cretaceous and Palaeogene events [42] [45]-[47]. After that the climate changes, as the transitional wetdry periods of the Quaternary, is controlling the rivers and the landscape in general, the same way it is controlling great part of the southeast Brazilian highlands as in Serra do Mar and Mantiqueira Mountain Range [48][51].

According to [36] summit levels and accordant summit heights are often interpreted as remnants of formerly more extensive denudation surfaces that have been formed by pediplanation or processes related to etchplanation. In Poços de Caldas Plateau summit levels and accordant summit heights have been interpreted as remnants of uplifted planation surfaces that correspond with denudation surfaces in the hinterland [9]-[17]; However the Late-Cretaceous and Paleogene ages obtained in this area shows that the surface in the upper area cannot be older, which proving that there are several limitations to use just the summit heights as evidence of dissected 
palaeo-surfaces [43] [52]. The thermochronological data is not supporting the Gondwana surface on the top [42] [45]-[47]. More data is needed to confirm the existence of those erosional surfaces in the area.

\section{Conclusion}

The SL Index from this area is highest comparing to the others, especially on the medium course of Machado River where it fits on a NE-SW fault that is probably related to the reactivation to the Ouro-Fino-Jacutinga shear zone. The morphometric analyses show that after the reactivation of the shear zones in the Triassic, there was a surface uplift, and a change on the river base level from the south to the north. The main rivers at that time like the Machado and Pardo start to adapt to the new structures and run to the north and northwest. The South Atlantic Opening reactivated the old faults in the area and generated new ones (NE-SW) adjusting once again the old rivers, especially on the lower intermediate level (where the AFT ages are from this period). Most of these structures are responsible for elevating the SL Indexes in those rivers. The drainage in PCAM was set up after the continental rift tectonic event in the beginning of Paleocene, explaining the low SL Index as the rivers are not being cut by the structures but they are installed inside the valleys formed by them.

\section{Acknowledgements}

The research was supported by Coordenação de Aperfeiçoamento de Pessoal de Nível Superior (CAPES). We especially thank Ana OlíviaBarufi Franco-Magalhães (UNIFAL, Poços de Caldas-MG) for the motivation and encouragement for writing this paper.

\section{References}

[1] Schobbenhaus, C., Campos, D.A., Derze, G.R. and Hasmus, H.E. (Coordenadores) (1981) Mapa Geológico do Brasil e da Área Oceânica Adjacente Incluindo Depósitos Minerais, Escala 1:2500000. Brasília DNPM, 4 Folhas, 400 p.

[2] Almeida, F.F.M., et al. (2000) The Origin and Evolution of the South American Platform. Earth-Science Review, 50, 77-111. http://dx.doi.org/10.1016/S0012-8252(99)00072-0

[3] Marques, L.S. and Ernesto, M.O. (2004) Magmatismo Tolé́tico da bacia do Paraná. In: Neto, V.M., Bartonelli, A., Carneiro, C.D. and Brito-Neves. B.B., Eds., Geologia do continente Sul-Americano: Evolução da obra de Fernando Flávio Marques Almeida, Editora Beca, São Paulo, 245-263.

[4] Zalan, P. V. and Oliveira, J.B.A. (2005) Origem e Evolução Estrutural do Sistema de Riftes Cenozóicos do Sudeste do Brasil. Boletim de Geociências da Petrobras, 13, 269-300.

[5] Ulbrich, H.H.G.J., Vlach, S.R.F., Ulbrich, M.N.C. and Kawashita, K. (2002) Penecontemporaneous Syenitic-Phonolitic and Basic-Ultrabasic-Carbonatitic Rocks at the Poços de Caldas Alkaline Massif, SE Brazil: Geological and Geochronological Evidence. RevistaBrasileira de Geociências, 32, 15-26.

[6] Thomaz Filho, A. and Rodrigues, A.L. (1999) O alinhamento de rochas alcalinas Poços de Caldas-Cabo frio (RJ) e sua continuidade na cadeia Vitória-Trindade. Revista Brasileira de Geociências, 2, 189-194.

[7] Ellert, R. (1959) Contribuição à geologia do maciço alcalino de Poços de Caldas. Boletim da Faculdade Filosofia, Ciencias e Letras, 237, 5-63.

[8] Ulbrich, H.H.G.J. and Ulbrich, M.N.C. (1992) O maciço alcalino de Poços de Caldas, MG-SP: características petrográficas e estruturais. XXXVII Congresso Brasileiro Geologia, São Paulo, SBG, Roteiro de Excursões, 1-64.

[9] King, L.C. (1956) A Geomorfologia do Brasil Oriental. Revista Brasileira de Geografia, 18, 147-265.

[10] Ab’saber, A.N. (2000) Summit Surfaces in Brazil. Revista Brasileira de Geociências, 30, 515-516.

[11] Keller, E.A. and Pinter, N. (1996) Active Tectonics: Earthquakes, Uplift, and Landscape. Prentice Hall, Upper Saddle River, 338 p.

[12] Keller, E.A. and Pinter, N. (2002) Active Tectonics: Earthquake, Uplift, and Landscape. 2nd Edition, Prentice Hall, Upper Saddle River, 362 p.

[13] Strahler, A.N. (1952) Dynamic Basis of Geomorphology. Geological Society of America Bulletin, 63, 923-938. http://dx.doi.org/10.1130/0016-7606(1952)63[923:DBOG]2.0.CO;2

[14] Hack, J.T. (1973) Stream-Profile Analysis and Stream-Gradient Index. Journal Research of United States Geological Survey, 1, 421-429.

[15] Troiani, F. and Della Seta, M. (2008) The Use of the Stream Length-Gradient Index in Morphotectonic Analysis of Small Catchments: A Case Study from Central Italy. Geomorphology, 102, 159-168. 
http://dx.doi.org/10.1016/j.geomorph.2007.06.020

[16] Christofoletti, A. (1980) Geomorfologia. 2nd Edition, Edgard Blucher, São Paulo, 188 p.

[17] Almeida, F.F.M. (1964) Fundamentos Geológicos do Relevo Paulista. Vol. 41, Boletim Instituto de Geografia e Geologia-IGG-USP, São Paulo, 169-263.

[18] Almeida, F.F.M. (1967) Origem e Evolução da Plataforma Brasileira. DNPM/DGM, Rio de Janeiro, 36 p.

[19] Heilbron, M., Pedrosa-Soares, A.C., Campos Neto, M.C., Silva, L.C., Trouw, R.A.J. and Janasi, V.A. (2004) Província Mantiqueira. In: Mantesso-Neto, V., Bartorelli, A., Carneiro, C.D.R. and Brito-Neves, B.B., Eds., Geologia do Continente Sul-Americano: Evolução da Obra de Fernando Flávio Marques de Almeida, Beca, São Paulo, 204-234, $647 \mathrm{p}$.

[20] Campos Neto, M.D.C. and Caby, R. (1999) Neoproterozoic High-Pressure Metamorphism and Tectonic Constraint from the Nappe System South of the Sao Francisco Craton, Southeast Brazil. Precambrian Research, 97, 3-26. http://dx.doi.org/10.1016/S0301-9268(99)00010-8

[21] Campos Neto, M.D.C. and Caby, R. (2000) Terrane Accretion and Upward Extrusion of High-Pressure Granulites in the Neoproterozoic Nappes of Southeast Brazil: Petrologic and Structural Constraints. Tectonics, 19, 669-687. http://dx.doi.org/10.1029/1999TC900065

[22] Ulbrich, H.H.G.J., Vlach, S.R.F., Demaiffe, D. and Ulbrich, M.N.C. (2005) Structure and Origin of the Poços de Caldasalkaline Massif, SE Brazil. In: Comin-Chiaramonti, P. and Gomes, C.B., Eds., Mesozoic to Cenozoic Alkaline Magmatism in the Brazilian Platform, Vol. 1, Editora da Universidade de São Paulo (EDUSP), São Paulo, 367-418.

[23] Almeida-Filho, R. and Paradella, W.R. (1977) Estudo do maciço alcalino de Poços de Caldas através da imagens Landsat com ênfase em mineralizações radioativas. Inpe-111-TPT/060, São José dos Campos, 130 p.

[24] Thompson, R.N., Gibson, S.A., Mitchell, J.G., Dickin, A.P., Leonardos, O., Brod, A.J. and Greenwood, J.C. (1998) Migrating Cretaceous-Eocene Magmatismin the Serra do Mar Alkaline Province, SE Brazil: Melts from the Deflected Trindade Mantle Plume? Journal of Petrology, 39, 1493-1526. http://dx.doi.org/10.1093/petroj/39.8.1493

[25] Almeida, F.F.M. (1991) O alinhamento magmático de Cabo Frio. Simpósio de Geologia do Sudeste, 2, 423-428.

[26] Bjornberg, A.J.S. (1959) Rochas clásticas do Planalto de Poços de Caldas. Boletim Faculdade. Filosofia Ciências Letetras, 18, 65-132.

[27] CPRM (1999) Programa de Levantamentos Geológicos Básicos do Brasil: Folha Santos, Guaratinguetá, Ilha Grande, Campinas, Escala 1:250000. Projeto de Integração Geológica-Serviço Geológico do Brasil, Superintendência Regional de São Paulo.

[28] Clark, M.K., Schoenbohm, L.M., Royden, L.H., Whipple, K.X., Burchfiel, B.C., Zhang, X., Tang, W., Wang, E. and Chen, L. (2004) Surface Uplift, Tectonics, and Erosion of Eastern Tibet from Large-Scale Drainage Patterns. Tectonics, 23.

[29] Whipple, K.X. and Tucker, G.E. (2002) Implications of Sediment Flux-Dependent River Incision Models for Landscape Evolution. Journal of Geophysical Research, 107, ETG 3-1-ETG 3-20.

[30] Korup, O. (2006) Rock-Slope Failure and the River Long Profile. Geology, 34, 45-48. http://dx.doi.org/10.1130/G21959.1

[31] Azañón, J.M., Pérez-Peña, J.V., Giaconia, F., Booth-Rea, G., Martínez-Martínez, J.M. and Rodríguez-Peces, M.J. (2012) Active Tectonics in the Central and Eastern Betic Cordillera through Morphotectonic Analysis: The Case of Sierra Nevada and Sierra Alhamilla. Journal of Iberian Geology, 38, 225-238.

[32] Darton, N.H. (1950) Configuration of the Bedrock Surface of the District of Columbia and Vicinity. United States Geological Survey Professional Paper, Vol. 217, Reston, 42 p.

[33] Hack, J.T. (1957) Studies of Longitudinal Stream Profiles in Virginia and Maryland. United States Geological Survey Professional Paper, 259-B, Reston, 45-97.

[34] Molin, P. and Fubelli, G. (2005) Morphometric Evidence of the Topographic Growth of the Central Apennines. Geografia Fisica e Dinamica Quaternaria, 28, 47-61.

[35] Hack, J.T. and Young, R.S. (1959) Intrenched Meanders of the North Fork of the Shenandoah River, Virginia. United States Geological Survey Professional Paper, 354-A, Reston, 1-10.

[36] Römer, W. (2000) Accordant Summit Heights, Summit Levels and the Origin of the "Upper Denudation Level” in the Serra do Mar (SE-Brazil, São Paulo): A Study of Hillslope Forms and Processes. Geomorphology, 100, 312-327. http://dx.doi.org/10.1016/j.geomorph.2008.01.001

[37] Lifton, N.A. and Chase, C.G. (1992) Tectonic, Climatic and Lithologic Influences on Landscape Fractal Dimensions and Hypsometry: Implications of Landscape Evolution in the San Gabriel Mountains, California. Geomorphology, 5, 77-114. http://dx.doi.org/10.1016/0169-555X(92)90059-W 
[38] Chen, Y.C., Sung, Q. and Cheng, K.Y. (2003) Along-Strike Variations of Morphotectonic Features in the Western Foothills of Taiwan: Tectonic Implications Based on Stream-Gradient and Hypsometric Analysis. Geomorphology, 56, 109-137. http://dx.doi.org/10.1016/S0169-555X(03)00059-X

[39] Bigarella, J.J. and Absaber, A.N. (1964) Paläogeographische und paläoklimatische Aspekte des Känozoikums in Südbrasilien. Zeitschrift für Geomorphologie, 8, 286-309.

[40] Bigarella, J.J. and de Andrade-Lima, D. (1982) Paleoenvironmental Changes in Brazil. In: Prance, G.T., Ed., Biological Diversification in the Tropics, Columbia University Press, New York, 27-39.

[41] De Melo, M.S., Stein, D.P., Ponçano, W.L. and Bistrichi, C.A. (1993) Neotectônica da área do Alto Rio Pardo (SP e MG). Revista do Instituto Geológico, 14, 27-38.

[42] Cobbold, P.R., Meisling, K.E. and Mount, V.S. (2001) Reactivation of an Obliquely Rifted Margin, Campos and Santos Basins, Southern Brazil. American Association of Petroleum Geologists (AAPG) Bulletin, 85, 1925-1944.

[43] Franco, A.O.B. (2007) Modelagem térmica e geomorfologia da borda sul do Cráton do São Francisco: Termocronologia por traços de fissão em apatita. Revista Brasileira de Geociências, 37, 76-86.

[44] Doranti-Tiritan, C., Hackspacher, P.C., Lima, H.C., Souza, D.H. and Rosante, K.T. (2010) Evolução da paisagem do Planalto Sul de Minas correlações entre análise morfométrica da rede de drenagem etermocronologia por traços de fissão em apatitas Revista de Geografia. Vol. Especial VIII SINAGEO, No. 1, UFPE-DCG/NAPA, Recife.

[45] Cogné, N., Gallagher, K. and Cobbold, P.R. (2011) Post-Rift Reactivation of the Onshore Margin of Southeast Brazil: Evidence from Apatite (U-Th)/He and Fission-Track Data. Earth and Planetary Science Letters, 309, 118-130. http://dx.doi.org/10.1016/j.epsl.2011.06.025

[46] Silva, J.D.S., Glasmacher, U.A., Hackspacher, P.C., Stoeckli, D., Karl, M. and Sehrt, M. (2011) The Poços de Caldas Alkaline Massif, a Key to Understand Thermal, Exhumation, Rock and Surface Uplift History at the "Passive" Continental Margin of Brazil. EGU General Assembly, Vol. 13, Vienna.

[47] Modenesi, M.C. (1988) Quaternary Mass Movements in a Tropical Plateau (Campos de Jordão, São Paulo, Brazil). Zeitschrift fur Geomorphologie, 32, 425-440.

[48] Coelho-Netto, A.L. (1999) Catastrophic Landscape Evolution in a Humid Tropic Region (SE-Brazil): Inheritances from Tectonic, Climatic and Land Use Induced Changes. Geografia Fisica e Dinamica Quaternaria III, 3, 21-48.

[49] Macgregor, D.S. (2012) Late Cretaceous-Cenozoic Sediment and Turbidite Reservoir Supply to South Atlantic Margins. Geological Society of London Special Publications, 369, 109-128. http://dx.doi.org/10.1144/SP369.7

[50] Dykes, A.P. and Thornes, J.B. (1996) Tectonics and Relief in Tropical Forested Mountains: The Gipfelflur Hypothesis Revisited. In: Anderson, M.G. and Brooks, S.M., Eds., Advances in Hillslope Processes, Vol. 2, Wiley, Chichester, 975-994.

[51] Summerfield, M.A. (2000) Geomorphology and Global Tectonics. Wiley, Chichester.

[52] Lima, H.C., Doranti, C., Hachspacher, P.C., Siqueira Ribeiro, M.C. and Brandini Ribeiro, L.F. (2010) Análise morfométrica da rede de drenagem da bacia do Rio do Machado-MG. Sociedade \& Natureza (Online), 22, 23-34. 
Scientific Research Publishing (SCIRP) is one of the largest Open Access journal publishers. It is currently publishing more than 200 open access, online, peer-reviewed journals covering a wide range of academic disciplines. SCIRP serves the worldwide academic communities and contributes to the progress and application of science with its publication.

Other selected journals from SCIRP are listed as below. Submit your manuscript to us via either submit@scirp.org or Online Submission Portal.
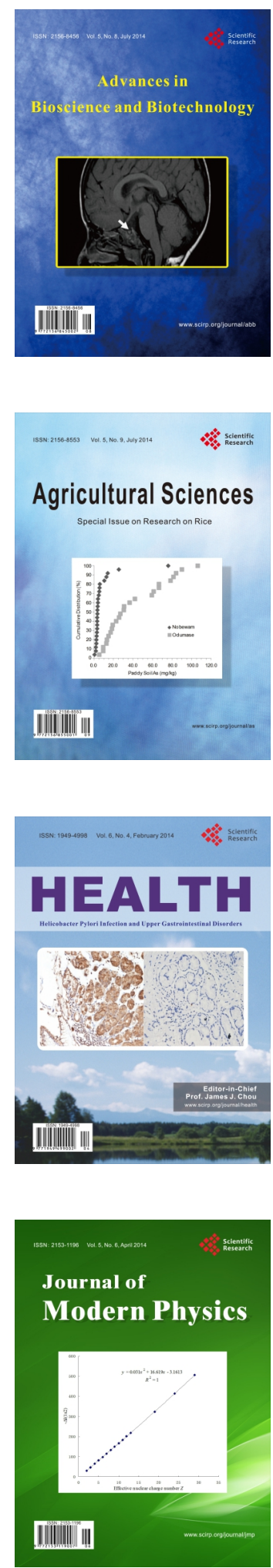
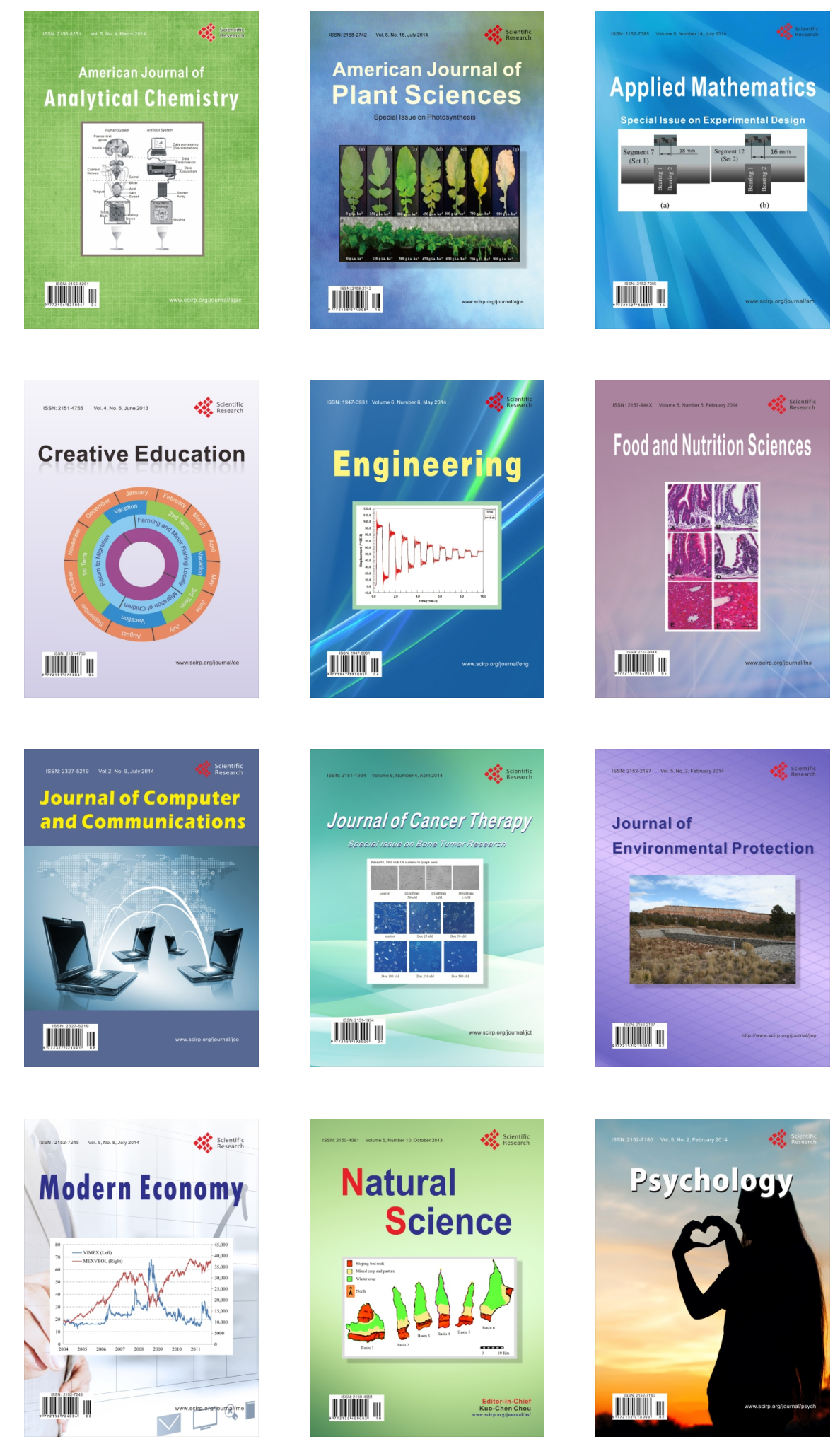